\title{
When and How do Bureaucratic Conflicts Matter in Trade Policy? Evidence from the US Trade Policymaking Process during the Clinton Administration (1993-2001)
}

\section{Rodrigo Fagundes Cézar ${ }^{*}$}

\begin{abstract}
The study of the role played by bureaucracies contributed substantively to the analysis of the domestic determinants of foreign policy outcomes, particularly by softening the premise of the state as a unitary-rational actor. However, the potential of focusing on bureaucracies to analyse US trade policy outcomes has been severely underestimated by the most recent IPE scholarship, which tends to focus on the Congress and interest groups, and to consider the Executive a unitary actor. Based on elements of the bureaucratic politics model, this article uses evidence from the US trade policy during Clinton's administration (1993-2001) in order to present arguments regarding how and when bureaucratic conflicts matter the most, and highlight the relevance of these conflicts in the trade decision-making process.
\end{abstract}

Keywords: United States; Executive; Trade Policy; Decision-making; Bureaucratic Conflicts.

\section{Introduction}

Back in the 1970s, the study of the role played by bureaucracies made a substantive contribution to the analysis of the domestic determinants of foreign policy outcomes. It softened the premise of the state as a unitary-rational actor, bringing in the role played by the diverse 'sub-governments' within the administration apparatus and the conflict among their distinct world-views when formulating and implementing foreign policies. Although Kissinger (1966) and others were already interested in analysing how domestic structures affected trade policy outcomes and criticised the 'traditional conception, [according to which] international relations are conducted by political units treated almost as personalities' (Kissinger 1966: 503), it was the model based on the book Essence of Decision (Allison

\footnotetext{
* Institut de Hautes Etudes Internationales et du Developpement (IHEID), Geneva, Switzerland; rodrigo.fagundes@graduateinstitute.ch.
} 
and Zelikow 1971) that took on prominence as one of the classical theories of foreign policy analysis (Hermann 2001).

Whereas previously to Allison's work studies on foreign policy usually took into consideration a direct relation between foreign policy actions and outcomes, the bureaucratic politics model (BPM) shed light on the analysis of the policy process that preceded the policy result. As expressed by the author, 'thinking about problems of foreign affairs, what most participants and analysts are really interested in are outcomes, and the specific actions governments take that effect outcome' (Allison and Zelikow 1971: 35). For the bureaucratic politics model, however, 'the way decisions are made affect the type of decision' (Art 1973: 469). With BPM, the study of bureaucracies has gained an astonishing proportion in the area of security and foreign policy studies, less so, however, when it comes to the study of US trade policy, as exposed in the next section. Based on elements of the BPM, this article uses evidence from the US trade policy during Clinton's administration (1993-2001) in order to present assumptions regarding how and when bureaucratic conflicts matter the most and highlight the relevance of these conflicts in the trade decisionmaking process.

The aim is that the evidence and hypotheses presented in this paper will contribute to making the bridge between the initial scope of the BPM, in general applied to security and foreign policies, and the trade policy subfield. The study of trade policy requires such an adjustment given the characteristics of the area, usually being more open to external pressures than traditional security policies. In that regard, it is important to highlight that this article is not an attempt to cover all possible bureaucratic interactions. It is my hope that further studies will expand the study and will include, for instance, clearer propositions about the relation between interest groups and bureaucracies. Nor is this article an attempt to amend BPM as a whole. Instead, it focuses on some theoretical elements which are relevant for the research on trade policy. As a result, my hope is that this paper will help make the study of bureaucratic conflicts more palpable for trade policy research. The primary interest of this article is to understand the dynamics of the trade policymaking process in its formulation and voting stages, and as such, I leave aside the BPM hypotheses regarding the implementation stage.

In order for this article to reach its objective, it will (1) illustrate the lack of scholarly attention towards the study of the US trade bureaucracy, make a very brief summary of BPM's elements, and review some of its main criticisms, and then (2) make some propositions using specific examples from Clinton's trade policy. The arguments I develop illustrate that bureaucratic politics do matter in the US trade policy, although not always will these divisions point to opposite agencies' world-views. They show, moreover, that seldom will bureaucracies reach a common ground in terms of trade policy; instead, those divisions are more likely to result in deadlocks, delays, and political 'zig-zagging.' I also present some arguments that show that the more polarised the U.S. Congress is, the deeper the bureaucratic conflicts, and that bureaucratic divisions are more pronounced during the formulation stages of a given policy. 
The empirical part of this research is mainly based on data from the online news services The New York Times, New Republic, and Inside US Trade, which were crucial for the process tracing undertaken by this research. In addition, I used insiders' accounts of historical events - such as Clinton's biography (Clinton 2004), the biography of Robert Rubin (Rubin and Weisberg 2003), former director of the National Economic Council (NEC) and former secretary of treasury, and the book edited by Orszag et al (2002), in which trade policy is presented by Laura Tyson, former director of NEC, among others. Apart from a handful of works such as Cohen, Paul and Blecker (2003) and Destler (2005), the scarce academic literature available received little scholarly attention.

Examples from the Clinton Administration were chosen as the basis for this paper's arguments as they offer a range of relevant cases that took place in similar contexts but with distinct outcomes. As such, they offer 'useful variation on the dimensions of theoretical interest' (Seawright and Gerring 2008: 296). Four events with different patterns of bureaucratic interaction are taken into consideration: the formulation and approval of NAFTA; the formulation of the China and Japan policies; and the attempt to get fast-track approved in 1997. Since they took place during Clinton's government and hold distinct values for the dependent variable (patterns of bureaucratic interaction), such cases are most similar. Instead of testing existing hypotheses, the primary interest of this article is to present arguments not yet available in the current trade policy scholarship, a goal more easily accomplished by small-N case studies (Levy 2008). Bearing that in mind, I expect the representativeness of the population investigated by this research to grow as a result of further studies that draw upon the theoretical elements sketched up by this article.

\section{The need for a more consistent study of the US trade bureaucracy}

It is true that there is a lack of attention towards the empirical and particularly the theoretical study of trade policy bureaucracy in spite of some relevant works published in the area in recent decades. Ian Destler, as an exponent of the area, led this scholarship with the bestsellers Making Foreign Economic Policy (Destler 1980), and American Trade Politics (Destler 2005), two thorough analyses of US trade policy history, along with other smaller publications such as National Economic Council: a work in progress (Destler 1996), focused on the role of honest brokers within the foreign economic bureaucracy. Other works such as that by Dryden (1994), Trade Warriors, also received some attention for their examination of the economic bureaucracy, particularly the role of the United States Trade Representative (USTR). Finally, The Making of United States International Economic Policy (Cohen 2000) and The Fundamentals of US Foreign Trade Policy (Cohen, Paul and Blecker 2003) close the 'hall of fame' of works that include an analysis of the US foreign economy bureaucracy - although in some cases the study of bureaucracies is not the primary focus.

The relevance of these groundbreaking works may give the false impression that the study of the US foreign economic bureaucracy is receiving due attention by recent trade policy scholarship. However, they are not indicative of the status quo of the literature, dominated by works that tend to consider the Executive as a unitary actor and that prefers to focus on the role played by the Congress, international economy, and interest groups 
in order to provide answers to US trade policy outcomes. These works departed from the classical tradition of the foreign policy analysis and engaged on the more parsimonious and generalisation-oriented political economy tradition, mainly by adapting the Ricardo-Viner and Stolper-Samuelson theorems to the political realm and by taking into consideration veto points as intervening variables. Representatives of this current include Mansfield and Milner (2008), Mainsfield and Henisz (2004), Scheve and Slaughter (2001), Alt and Gilligan (2001), and Frieden (2000). Another current includes authors investigating the impact of a divided government on cooperation (Milner 1997; Lohmann and O'Halloran 1994; Karol 2000). Among other things, what all these works have in common is that they are not interested in the divisions within the Executive in order to avoid theoretical complications that could jeopardise their theoretical parsimony.

This trend is evidenced by critics of the growing reductionism of the modern IPE such as Cohen (2000) and is backed by the number of trade policy articles based on the political economy tradition. These publications (1) are more recent, (2) are numerous and constantly appear in high impact factor journals, such as International Organization, British Journal of Political Science, American Journal of Political Science, Comparative Politics Journal, etc., and (3) receive scholarly attention, which can be tracked by the number of authors referring to them in their works. On the other hand, while Destler's (2005) book, for instance, was quoted by more than a thousand works, it is hard to find articles and books from outside the abovementioned 'hall of fame' that received the same attention in recent years. In addition, most of these reference works are neither theory-oriented, nor bureaucracy-focused. Actually, a great extent of the success of some of these works is dictated by their usefulness as trustworthy trade policy handbooks, offering a broad account of US trade history, without presenting any contribution in the theoretical realm or even having bureaucracies as the main object of study.

Taking into consideration the last 15 years, only a handful of relevant academic articles with empirical focus on the US trade bureaucracy have been published (Dolan 2003; Dolan and Rosati 2006; Destler 2010), and these serve as the basis for this research. With regard to theory, the situation is even more challenging. The literature review made by this paper found only one theory-oriented work on the US trade policy bureaucracy published in a journal with impact factor greater then 1.5 (Dolan 2003) in the last 15 years. This work received scarce scholarly attention, with a considerably lower number of references than the most recent political economy-oriented US trade policy papers. For these reasons, Destler (2010: 1) himself lamented that foreign economic bureaucracy had 'received surprisingly little attention among students of American foreign policy'.

Faced with this discrepancy, one might ask: Does the study of bureaucratic conflicts actually matter that much to US trade policy research? Is it important to think about these conflicts in a theoretical way? The evidence presented in this article offer positive response to both questions, pointing out the need for more consistent US trade policy bureaucracy works. By showcasing this evidence, this paper will hopefully contribute to the existing literature and help address the lack of 'non-hall of fame' works focused on foreign trade bureaucracy. In order to contribute to that objective, the next section illustrates the main elements surrounding BPM and its major criticisms. This serves as a basis for the subse- 
quent section, which presents assumptions regarding important characteristics of bureaucratic conflicts in trade policy and the moments in which they matter the most.

\section{Bureaucratic politics model: summary and review of criticisms}

The BPM is an approach that places itself as an alternative to the rational choice model, which considers the state a unitary and rational actor. It is based on the evidence that few foreign policy decisions are straightforward and based on an ideal of national interest. According to BPM, there are many conceptions of national interest within the national borders. As such, treating the state as unitary and rational for means of simplification and generalisation 'obscures to the same extent it reveals... [T] he players make choices not in terms of a set of strategic objectives, but instead according to various concepts of national interest' (Allison and Halperin 1972: 42). Each agency within the Executive sees the national interest as a reflection of its own interests and 'will fight for what they are convinced is right' (Allison and Zelikow 1971: 145). In turn, no single actor has the monopoly over the decision-making process, not even the president, although the 'power and skills' of the actors do matter.

In order to determine the actors' preferences, the BPM takes into consideration individual, institutional, and contextual elements. However, what becomes rather clear is the primordial role played by institutional aspects, reflected in the proposition 'where you stand depends on where you sit'. According to Allison and Zelikow (1971), in each bureaucratic agency there is a set of values and facts accepted without discussion by most of the actors that are part of the organisation, and these actors interpret the state's action in light of these values and facts. Given that power is shared among these agencies, for the BPM the decision-making process takes form through consensus building among distinct participants. Consensus is only reached through bargaining and negotiation, and for each foreign policy there is a resultant, which is the by-product of the compromise reached by bureaucratic actors involved in the policymaking process, 'a mixture of conflicting preferences and unequal power of various individuals' (Allison and Zelikow 1971: 145). The resultant is defined by the reputation and resources available to each agency, as well as the perception of other actors as to the available resources of the actors involved.

The mainstay of the BPM is, thus, the existence of conflicts among distinct bureaucratic actors for assuring its survival and influence in the policymaking process. Moreover, as further advanced by the iron triangles literature, bureaucratic actors may also defend private interests associated with the possibility of reaching positions within the private sector after leaving the government (revolving doors). Be that as it may, bureaucratic politics is, par excellence, a model centred on bargaining. However, it did not take long until the model attracted criticism. Krasner (1972), George (1973), Art (1973), and Freedman (1976) were the first to attack the model, and new criticisms also arose throughout the decades, as pointed out by the works of Bentor and Hammond (1992), Welch (1992), and Rhodes (1994). In terms of theory, these authors criticise the inaccuracy and excess of variables present by the bureaucratic politics model. In relation to the model's core assumption - the importance of bureaucratic conflicts, which is of interest for the present 
article - the main criticisms are based on the following aspects: 1) lack of attention to the Congress; 2) lack of attention to the President and other external actors; 3) exaggeration of the distinct bureaucrats' objectives and goals; 4) lack of applicability of the resultant hypothesis.

\section{Lack of attention to the Congress}

The first and most relevant argument presented by critics of the BPM is based on the evidence that nowadays the role played by the Congress cannot be ignored in the formulation of foreign policy. As pointed out by Hilsman (1969 cited in Art 1973: 456), 'it is obvious that the proposals of the Executive are moulded by the perspectives of how the Congress and the congressmen, individually, will react, the mood of the Congress, and the probability, circumstances and possible means they can use as a counterpoint. Very close to the rational assumptions of the dominance of the Congress (McCubbins and Schwartz 1984), Art (1973) and Krasner (1972) also argue that it is the preference of the Congress that matters, instead of that of the Executive. Some critics go further and claim that the lack of attention of BPM to the pluralist logic of contemporary politics is 'misleading, dangerous and compelling' (Krasner 1972: 459).

\section{Lack of attention to the President and other external actors}

In addition, some authors consider that not always will bureaucratic conflicts require a time-consuming process of creating consensus as long as there is an external actor to help overcome these difficulties. Jerel Rosati (1981), for instance, refers to the relevance of the president and the prospect that his participation in moments of crisis might result in bureaucratic conflicts being suppressed in favour of the presidential approach towards foreign policy. Other works, in turn, analyse bureaucratic politics in the context of relations among interest groups, the Legislative, and the Executive (Bendor and Moe 1985). Other authors, such as George (1972), criticise the BPM based on the lack of understanding of that model regarding the participation of multiple advocacy agencies as a sort of a 'honest broker' capable of managing distinct points-of-view within the Executive by means of a 'neutral perspective, devoid of passions, and coherent with the President's view' (Cohen 2000: 171).

\section{Overestimation of the distinct bureaucrats' objectives and goals}

The outlook of post-War US foreign policy led Art (1973: 476) to ask himself: 'If shared images dominate senior players' outlooks and if they are truly shared, then what is the merit in asserting that governmental actions are the resultants of pulling, hauling and bargaining?' For the author, the result of the existence of a set of shared beliefs among policymakers 'is to give much more weight to the nation-state-as-unitary-actor view than the bureaucratic paradigm would lead us to believe' (Art 1973: 476). Not only Robert Art has made such a criticism. Bentor and Hammond (1992) and Rhodes (1994) also consider that policymakers do not necessarily have different world-views. In trade policy this is particularly interesting, given that Goldstein's (1986) very relevant finding regarding the existence of a 'bias' favourable to trade liberalisation within the US executive apparently 
gives backing to the argument of Art (1973). Pastor (1982) also supports the unitary-actor assumption by claiming that, in his trade policy study, 'while coalitions were sometimes organized between Congress and committees, the rule in many of the policies analyzed was that Congress and the Executive approached issues as coherent, unitary organizations...' (Pastor 1982: 345).

4. Lack of applicability of the resultant hypothesis

One of BPM's main hypotheses regards the existence of a resultant, described as the product of bargaining games among distinct agencies' approach towards foreign policy. This hypothesis is also called into question by critics such as Art (1973) and Rosati (1981), to whom the BPM does not make any distinction regarding the moments in which the process of bargaining within the Executive indeed makes a difference in the formulation of foreign policies. Bureaucratic divisions often do not generate a resultant. Instead, they give space for deadlocks and delays in the entire policymaking process. Moreover, as stated above, not always will conflicts result in a consensus, given that some specific agencies may have the power to eclipse others. Also, the President's active participation in the process may give him leeway to decide, on his own, the path to be followed by the Executive in case there is, for instance, a persisting stalemate in the formulation process (Art 1973).

All of these criticisms are relevant; however, most times critics are not interested in asking when a given element of the framework matters instead of only wondering if the model is useful or not. Some works, such as those by Jerel Rosati (1981) and Bendor and Moe (1985), are exceptions and must be given credit. Moreover, the criticisms themselves are imperfect. Art (1973) and Krasner (1972) give too much credit to the importance of the congressional dominance. Most times they are not interested in wondering if the mechanisms of oversight created by the Legislative are indeed capable of controlling the agent (bureaucracies). Moreover, George (1972) and Art (1973) also do not take into consideration the fact that the president may be deeply involved in other issues, which may constrain his active participation in the dynamics of the policy process unless there is a clear motivation for him to do so, as pointed out by Rosati (1981).

In order to tentatively address these four main criticisms, the next section will rely on evidence taken by the Clinton administration (1993-2001) and focuses particularly on the trade policy sphere in order to analyse some important characteristics of bureaucratic conflicts and determine occasions on which they are more relevant in the US trade policymaking process.

\section{Bureaucratic conflicts in trade policy: evidence from Clinton's administration}

The trade policymaking process in the United States is characterised by fragmentation. According to Alice Rivlin - Chair of the US Office of Management and Budget between October 1994 and April 1996 - as quoted by Destler (1996: 2), the trade decision-making process 'is so fragmented and complicated that it is almost impossible to explain to the uninitiated how it is supposed to work, let alone how it does work. Cohen (2000: 12), in turn, considers the US trade decision-making process extremely fragmented, complex and even chaotic. Table 1 gives 
a clear dimension of that by presenting the bureaucratic agencies with foreign economic policy departments.

Table 1. Departments and agencies with foreign economic policy bureaus

\begin{tabular}{|c|c|}
\hline \multirow{3}{*}{ Department of Agriculture } & Office of Energy Policy \\
\hline & Global Change Program Office \\
\hline & World Agricultural Outlook Board \\
\hline \multirow{4}{*}{ Department of Commerce } & Bureau of Economic Analysis \\
\hline & Economic Development Administration \\
\hline & International Trade Commission \\
\hline & Technology Administration \\
\hline \multirow{3}{*}{ Department of Energy } & Energy Advisory Board \\
\hline & Office of Nuclear Energy Technology \\
\hline & Policy and International Affairs Office \\
\hline \multirow{5}{*}{ Department of Justice } & Drug Enforcement Administration \\
\hline & Environment and Natural Resources \\
\hline & Federal Bureau of Investigation \\
\hline & Foreign Claims Settlement Commission \\
\hline & Immigration and Naturalization Service \\
\hline \multirow{6}{*}{ Department of State } & Economic and Business Affairs \\
\hline & Educational and Cultural Affairs \\
\hline & International Narcotics and Enforcement \\
\hline & Population, Refugees, and Migration \\
\hline & Trafficking in Persons \\
\hline & Western Hemisphere Affairs \\
\hline \multirow{6}{*}{ Department of the Treasury } & Bureau of the Public Debt \\
\hline & Financial Management Service \\
\hline & Internal Revenue Service \\
\hline & Bureau of the U.S. Customs Service \\
\hline & Office of Economic Policy \\
\hline & Office of International Affairs \\
\hline
\end{tabular}




\begin{tabular}{|c|c|}
\hline \multirow{12}{*}{ Other Agencies } & National Security Council \\
\hline & National Economic Council \\
\hline & Office of Science and Technology \\
\hline & Policy \\
\hline & USTR \\
\hline & Council of Economic Advisers \\
\hline & U.S. Export-Import Bank \\
\hline & Federal Reserve System \\
\hline & Overseas Private Investment Corporation \\
\hline & Trade and Development Agency \\
\hline & Environmental Protection Agency \\
\hline & Agency for International Development \\
\hline
\end{tabular}

Among these agencies, the United States Trade Representative (USTR) is currently responsible for the 'overall' trade policy formulation, ${ }^{1}$ although its role has changed over the years (Dryden 1995). However, trade policy has implications in terms of international security, international finance, society, and economy, as it also has electoral spill-overs (Cohen, Paul and Blecker 2003). Thus, it is unrealistic to think that the USTR will reign without being contested. In view of that, the most relevant innovation of the BPM is that it does not assume the existence of a straightforward relation between foreign policy objectives and results. Faced with the above criticisms, however, it is necessary to go further in the exploration of the characteristics of bureaucratic conflicts, particularly regarding the kind of conflict that may arise, the characteristics of the resultant, and the relationship with the Congress.

\section{Insights on the characteristics of bureaucratic conflicts based on trade policy cases}

As pointed out above, one of the criticisms made by Art (1973) is that BPM does not take into consideration shared beliefs and world-views that could potentially constrain bureaucratic conflicts. Indeed, some historical institutionalist authors such as Goldstein (1986) and Chorev (2010) have showed that when it comes to trade policy the US Executive is on average favourable of trade liberalisation. However, instead of showing a unitary executive, the positions of Chorev and Goldstein can both be illustrated by the idea of 'conflict amid consensus', as defended by Martha Gibson (2000). The analysis of Goldstein (1989), for example, clearly shows the clash between the policymakers associated with the farming and industrial sectors. What came to be understood by the US foreign trade policymaking is that trade liberalisation in the United States can only be accomplished if protectionist interests are somehow accommodated. Based on that, the idea of free and fair trade provided the necessary background to allow leeway for the US Executive to both pursue reciprocal trade liberalisation along with its trade partners and offer side payments to groups which are wary of the free-trade idea (Goldstein 1986; Chorev 2010). 
This line of action, as illustrated by Goldstein (1986; 1989), arose from two different traditions: a political reaction to the high trade barriers during the Great Depression and the need to protect industry and agriculture against unfair trade. Based on that, the liberal 'bias' of the US trade bureaucracy does not overshadow the possible conflicts between free and fair trade defenders within the Executive. While it waters down the idea that bureaucratic politics does not actually matter, it does mean, however, that the differences within the US executive, as a reflection of US trade policy institutionalisation, are not as contrasting as one could possibly consider. Table 2, below, presents, in a very simplified fashion, the typical position of some US Executive agencies.

As an example, during the NAFTA process, there were two distinct groups advocating in favour of specific ways of dealing with side agreements. On the one hand, Robert Rubin (Director of the National Economic Council), Lloyd Betsen (Secretary of Treasury), and Warren Christopher (Secretary of State) were part of the group defending NAFTA's approval without vigorous labour and environmental clauses. On the other hand, Mickey Kantor (US Trade Representative), Robert Reich (Secretary of Labor), and Carol Bowner (Environmental Protection Agency) were part of the group that wanted an agreement 'with teeth', in which NAFTA's labour and environmental side agreements would include the possibility of sanctions (Judis 1995). These groups were not against NAFTA. Rather, they were in favour of different provisions to be included in its side agreements. Some officials also discussed whether NAFTA should be voted on immediately or only after the healthcare debate (Dolan 2002). These divisions proved relevant and triggered delays in the policy process.

Table 2. Typical position of selected US bureaucratic agencies towards trade policy

\begin{tabular}{ll}
\hline Department of State & $\begin{array}{l}\text { Supports trade liberalisation and usually refrains from imposing } \\
\text { sanctions on strategic partners that are important for the US } \\
\text { international security strategy, such as Japan and China. It considers } \\
\text { that trade policy must reinforce US foreign policy strategy. }\end{array}$ \\
\hline $\begin{array}{l}\text { Supports trade liberalisation and gives particular attention to the } \\
\text { interest rates of the international economy; major objective is to keep } \\
\text { an environment favourable to private investment and to the value of the } \\
\text { US dollar }\end{array}$ \\
$\begin{array}{l}\text { Supports trade liberalisation and the expansion of US exports in an } \\
\text { aggressive manner, if necessary, in order to open markets; responsible } \\
\text { for the application of some of the US trade remedies. }\end{array}$ \\
$\begin{array}{l}\text { Department of Commerce } \\
\text { Representative (USTR) }\end{array}$ \\
$\begin{array}{l}\text { Supports the promotion of fair and free trade; seeks access to foreign } \\
\text { markets for US businesses and protection of industries from 'unfair' } \\
\text { practices. Historically, it has also played the role of honest broker. }\end{array}$ \\
\hline
\end{tabular}


Favourable to the trade preferences of the president, which are usually biased towards liberalisation (liberal presidency thesis [1]). Assertiveness depends on the participation of the president and the members indicated to run the Council

Supports fair trade; faces a split between import-sensitive (e.g. sugar and peanut) and export-oriented (e.g. soybeans, corn and wheat) producers. With a relevant share of its constituency being politically powerful import-sensitive producers, constant side payments are due in order to pursue further trade liberalisation.

nited States Department of Agriculture (USDA)
Supports fair trade; has recently supported the inclusion of strong

Department of Labor labour clauses in trade agreements; in spite of being wary of trade liberalisation, has not opposed big agreements such as NAFTA.

[1] According to the liberal presidency thesis (Karol 2000), usually the President's preferences do not change in response to their party affiliation. It means that both Republican and Democrats presidents are in general in favour of trade liberalisation.

Source: Based on Destler (1996; 2005), Cohen, Paul and Blecker (2003), and Cohen (2000)

Take, in addition, the example of the formulation of Clinton's Japan policy between 1993 and 1995. It took place in a moment in which the United States ran growing trade deficits in its relationship with Japan. These deficits gave rise to heated debates surrounding the need to reverse that outcome. Although there was not an initial division among different agencies - and in fact, the president of the United Auto Workers (UAW) even commented that there was an unprecedented sense of common purpose within the government (Inside US Trade 1993d) - soon a division between the USTR and the Department of Treasury flourished. The USTR saw the need to seek a 'results-oriented' approach towards Japan in order to reduce the trade deficits. Mickey Kantor, then US trade representative, considered the need to be straightforward in the pursuit of such a goal by reviving, for instance, the aggressive trade remedy called Super 301. In turn, the Department of Treasury, backed by Laura Tyson, then director of NEC, supported a more flexible approach (Dolan 2002). Note that the two sides were not opposing each other. On the contrary, they were trying to find the best tactic to pursue a 'free and fair trade' objective.

Another example is Clinton's China policy. In 1994, the United States was looking for a more conciliatory approach towards China. In spite of complaints of human right abuses that soured the relationship between the two, the Department of State wanted to make sure it would have the upper hand regarding the relationship with the Asian country: 'The Secretary is trying to keep the Commerce and Treasury Departments from trying to make a run over taking over the policy. He wants to make sure State Department keeps a very strong control over the China relationship, that it's not tenable to have the economic agencies in open revolt against the policy' (Sciolino 1994: 1). By the same token, divisions over the best balance between free and fair trade also contributed to the delay of the fasttrack $^{2}$ vote, having as a possible result a badly coordinated position towards the Congress. While on the one hand the Department of Labor, the Environmental Protection Agency (EPA), and, to a certain degree, the USTR advocated in favour of incorporating labour and environmental issues as negotiating objectives in the fast-track authority, the National Economic Council wanted to leave aside such aspects (Clinton 2004). 
These examples illustrate that agencies dealing with trade policy will not necessarily have conflicting world-views, but are likely to clash over the best free-fair trade balance. These conflicts may also be explained by the fact that bureaucracies and bureaucrats are bounded rational actors. In other words, their rationality is limited by the available information, by the time available to make decisions, and by cognitive limitations. If there is no outside actor who can help coordinate the process, or when time does not exert pressure in favour of a quick agreement, bureaucrats can potentially extend discussions for much longer than would be assumed by the rational actor premise. The result is that conflicts may build momentum and exert relevant impact on the policy process, given that these agencies - when allowed leeway - are likely to try to shape a given policy according to their preferred tactics.

Based on these examples, it is possible to argue that:

Argument 1: In trade policy, bureaucratic conflicts usually arise over the fair tradefree trade balance considered more efficient by the Executive agencies.

As pointed out above, another main criticism of the BPM is that it does not consider the participation of the Congress. The Executive has to be always attentive to the preferences of the Legislature, because it has the power to create regulations that limit the autonomy of the agencies. As presented by the rational choice institutionalism, the Congress has oversight mechanisms to control the Executive, which sees its autonomy limited by the Congress's vigilance. Because of that, as pointed out by Cohen, Paul, and Blecker (2003), the Congress is a direct or indirect factor that influences each substantive decision in terms of trade policy:

Senior trade officials understand that if an administration too frequently acts in a manner contrary to prevailing congressional sentiment, it invites interbranch retaliation. The more a majority of members become alienated, the more likely they are to refuse an administration's requests for new trade statutes or to pass legislation that the administration did not ask for and does not support (Cohen, Paul and Blecker 2003: 113).

In view of that, the Executive is constantly trying to accommodate the preferences of the Congress and to consult it whenever it thinks that acting otherwise would result in retaliation. This is so not only because the Congress has the power to create rules that might tame the Executive's autonomy, but also because the bureaucracy must present an acceptable proposal to the Congress in order to get its approval.

For instance, Clinton, who had been elected based on the promise of giving priority to workers, and who was closely advised by Mickey Kantor (USTR), in his first year approved an agreement (NAFTA) which was considered unsatisfactory when it comes to the enforcement of labour rights. According to Dolan (2002: 135), the initial strategy led by USTR was compromised' by the need for reassuring that the preferences of the Republicans would be taken into consideration, which meant that strong side agreements were not viable if Clinton wanted to reach a bipartisan majority in the voting of NAFTA. 
In other words, the interaction with the Congress ended up altering the status quo of the bureaucracy towards the group more favourable of soft side agreements.

In addition, during the formulation of the China policy, it was clear that the intention of the administration was to get as close as possible to Congress preferences. Nanci Pelosi (D-CA), for instance, affirmed that while the Congress was interested in making concessions, it would intervene should Clinton not be able to position himself in an assertive manner towards China (Inside US Trade 1993b). In another occasion, in turn, the Congress once more exerted influence when the United States decided to delink the approval of the annual most-favoured nation status to China to improvements in its human right records. 'The president took for himself the onus, the burden of recognizing the shift in our policy, a step that many in Congress asked us to take' (Inside US Trade 1994a: 1). The same applied to the Japan strategy, which was in close association with the preferences of the Congress, particularly those advocated by Robert Gephardt (D-MO) (Inside US Trade 1993c). In the very beginning, the Japan policy counted on a consensus between Republicans and Democrats regarding the need for a more assertive position towards Japan. This consensus influenced the position of the Executive, making the status quo favourable for groups defending more active intervention.

During the fast-track debate in 1997, in turn, there was the need for an effective proposal in view of the importance that the administration attributed to the passage of the authority in that specific year. As such, it was important to pay close attention to the preferences of the Congress in order for the fast-track not to result in a badly co-ordinated effort risking not being approved by the Congress in 1997. The term used by Clinton (2004) regarding the relation between the Executive and the Congress is illustrative: a mix of 'compromise and guerrilla war.' Due to the importance of the Congress, the former US trade representative, Charlene Barshefsky - as further explored below - would not consider the fast-track proposal ready before she was sure it was deemed acceptable by the Congress. This approach gave rise to fierce discussions between Barshefsky's allies and the other bureaucrats who considered the fast-track should be voted on early in 1997 (Devereaux et al 2006).

These examples illustrate that:

Argument 2: The interaction between the Congress and Executive agencies has a feedback effect on bureaucratic conflicts.

Arguments 1 and 2 impact BPM's resultant hypothesis. I agree with Art (1973), to whom bureaucratic conflicts do not necessarily determine a resultant, which in the BPM takes the form a common denominator among the agencies involved in the discussion. If bureaucratic politics are relevant and if the Congress influences the position of the bureaucracy, it may be that bureaucratic conflicts actually result in political 'zig-zagging' in the formulation process instead of leading to a 'resultant' among distinct agencies. This can only be overcome by the active participation of an effective agency brokering the process.

During the NAFTA debates, for example, the National Economic Council faced constraints while trying to broker the preferences of the agencies participating in the policy process. Secret documents were leaked and the meetings of NEC were marked by the presence of a large number of actors, some of them only peripherally involved in the issues 
being discussed (Destler 1996). These constraints reduced the efficacy of the NEC as an honest broker and resulted in a common denominator not being successfully found. Only with the active participation of the president was the political zig-zagging between the proponents of more-/less-assertive side agreements to protect the environment overcome.

During the formulation of the Japan policy, USTR and the US Congress were resolute that there should be a more assertive approach towards that country and its supposed 'unfair' trade practices. In the beginning, while the participation of Mack MacLarty as chief of staff contributed to an effective brokering of the preferences within the Executive (Rubin and Weisberg 2003), bureaucratic divisions did not take long to surface, as already expressed. The Department of Treasury was not in favour of the USA having such an assertive position in view of Japan's strategic position in the Pacific, although it did consider that Japan should open its borders to US exports. The Department of Commerce seemed to have offered some backing to the position of the Department of Treasury, and Jeffrey Garten, Subsecretary of Commerce, stated that the administration would like to observe a 'new kind of relationship with Japan' (Bradsher 1995: 1), a statement immediately rejected by Charlene Barshefsky (USTR), who considered Garten a 'dissonant voice.'

This division within the administration was not overcome by a 'resultant.' It resulted in an apparent indefinition in terms of the best approach towards Japan. Tyson, for instance, after finally signalling the possibility of a softer approach towards Japan because of (1) difficulties in the negotiations, (2) the possibility of Japanese retaliation, and (3) internal opposition, faced criticism from the Congress (Inside US Trade 1994b). Given that no middle ground could be immediately found, what followed was moments in which sanctions were seen as a viable policy option and moments in which they were discarded, contributing for the existence of a 'cacophony' within the administration (Dolan 2002: 243).

Arguments about the possibility of bureaucratic conflicts not being overcome by resultants - instead resulting in delays in the policy process - are particularly relevant because when a given measure needs to be voted on, delays/stalemates will result in the administration having less time to lobby the Congress in favour of the measure. This is so because an all-out support by interest groups and congressional representatives sympathetic to trade liberalisation is more difficult to achieve unless there is a clear proposal on the table. During the fast-track fight, the business coalition America Leads on Trade (ALOT) was willing to give its full support to the administration only after a solid proposal was presented (Inside US Trade 1997a), and such a proposal did not come in time due to bureaucratic divisions over when to present such a proposal. The Republicans, in turn, advised business leaders that they would not 'do anything until we have a defined language' (Devereaux et al. 2006: 218), in allusion to the way the final proposal would approach labour and environmental aspects.

Based on these examples:

Argument 3: When a common denominator cannot be easily found or no agency can coordinate or suppress conflicts, bureaucratic divisions will instead result in political 'zig-zagging' with consequences in terms of coherence and delays/stalemate in the policy process.

Although the above arguments by no means fully address all the possibilities regarding bureaucratic politics in trade policy, they shed light on some important elements that 
may be of good use for future studies. They illustrate that: 1) conflicts may take place even considering that the US trade bureaucracy has a liberal bias, as pointed out above; 2) the interaction between the Congress and the Executive has a feedback effect on bureaucratic conflicts; and 3) they will not necessarily result in a common denominator. However, these elements do not address the considerable degree of indetermination that exists in the analysis of bureaucratic divisions. The BPM implicitly assumes that bureaucratic divisions will be important at all times; however, it is clear that there are specific moments in which bureaucratic conflicts are more relevant. Which moments are these?

\section{The occasions on which bureaucratic divisions are more likely to exert impact in the policy process}

The existing BPM critiques do not take into consideration the division between the formulation and the voting phases of a given policy in order to understand when bureaucratic conflicts are more prominent. In that regard, the following examples illustrate that, close to the voting date, bureaucratic divisions are likely to be less intense. This is so because the possibility of losing a Legislative battle becomes the glue that holds the bureaucracy together, bringing the president in, even if in other moments his attention is somewhere else. The division between the formulation and voting stages is an important one, given that, as pointed out above, with few external constraints - pressures from the President or the Congress, for instance - the bureaucracies are likely to dwell on the elements of trade policies. In addition, the president, whose participation is so relevant to overcome bureaucratic conflicts (Rosati 1981), may not be able to participate or be interested in being part of the process during the formulation stage if there are other relevant issues being debated. As pointed out by Cohen, Paul and Blecker (2003: 138), 'because presidential time and energies normally are concentrated in other policy sectors, most decisions in trade policy are made at or below the cabinet level [...].'

For instance, during the period in which the United States was bargaining over the conditions for granting the permanent status of most favoured nation (permanent normal trade relations - PNTR) to China, ${ }^{3}$ a series of bilateral meetings did not result in agreements, in spite of Prime Minister Zhu Ronghi's substantive concessions to the USA. The failure to reach an agreement was largely the result of a bureaucratic conflict between John Podesta (Chief of Staff) and Gene Sperling (Director of NEC) and officials from the Department of State and USTR. Podesta and Sperling were against a possible agreement, fearing that it would not be approved by the Congress, while USTR and the Department of State were favourable, considering that if the agreement was not approved at that moment, the USA's window of opportunity would close (Sanger 1999; Dolan 2002). According to David Sanger, from the New York Times, this coordination failure was a direct result of the President's absence:

As the White House debate rolled on, Clinton was busy with other things. He spoke with Ms. Barshefsky only sporadically; she made a last-minute trip to Beijing last week without a clear sense of what the 
President wanted. There were few meetings to prepare the President for a major meeting with Zhu. 'He could barely focus on the summit', said a foreign policy aide. So by the time Clinton was deeply involved in the details, it was clear that negotiators had run out of time to complete a deal that might have been acceptable to both China and Congress (Sanger 1999: 1).

The absence of Clinton's guidance during the initial meetings with China, along with the absence of a legitimate honest broker to translate the President's preferences into action, can be traced as one of the main motives why an agreement with China was not reached at that moment. His absence can be explained by the tight agenda and lack of sense of emergency in giving more attention to the issue at hand. On the other hand, during the voting stage of China's PNTR, Clinton's participation was much more pronounced. Clinton created a 'China room' in the White House to coordinate the lobbying effort and kept himself engaged in the process. According to Samuel Berger from the National Security Council, ' $\mathrm{t}$ ] he effort in course is more substantial than anyone else I have seen during the seven years I have been in the White House' (Babington and Vita 2000).

At those moments - close to the voting date - the bureaucratic division within the Executive retreated. In spite of different perceptions as to the best free-fair trade balance, which can lead to heated conflicts, the bureaucracy is likely to be united by a sense of purpose when confronted with the Congress, or by upright pressures coming from the president. For instance, Robert Reich, Secretary of Labor in 1993, in spite of being initially hesitant, gave his full support to NAFTA in April 1993 (By 1993), as the result of pressure from within the administration (Reich 1998). Further into the process of getting NAFTA approved, Clinton personally lobbied the Congress until the last minute before the voting, and he had massive support from the bureaucracy in spite of previous divisions, as noted above.

This was also the case with the attempt to renew the fast-track authority. On the one hand, it is true that during the formulation of a fast-track proposal in 1997 the president was not present because he was busy negotiating the 1998 Budget Plan and the renewal of the most-favoured nation status to China, which were more pressing issues in his agenda than trade policy. It is also true that this absence contributed to the lack of clear directions for the bureaucracy, this being one of the elements - although not the only one - that explain the bureaucratic conflicts in the fast-track process (Orszag et al. 2002). On the other, it is also true that in October 1997, some weeks before the expected voting date, Clinton was not doing anything else but lobbying in favour of the fast-track (Clinton 2004). In sum, while during the formulation of a proposal by the Executive, agencies are given more leeway to engage in discussions over the best shape of an agreement and sometimes are not able to reach a common position (Arguments 1 and 2), during the voting stage, they act together in order (1) to avoid a Legislative loss and (2) to support the lobbying effort of the president towards the Congress.

Argument 4 can be drawn from these examples:

Argument 4: Bureaucratic conflicts are more intense during the formulation stage, while during the voting stage divisions tend to fall apart, to a great extent as a response to the participation of the president and the need to win the battle with Congress. 
There is one point yet to be addressed by this article. As presented above by Argument 3 , the interaction between Congress and executive agencies has a feedback effect on bureaucratic conflicts. This means that the bureaucracy has to be attentive to the preferences of the Congress not to trigger possible interferences that affect the agencies' autonomy and to formulate a proposal with higher probability of being approved. However, when does that feedback more prominently affect bureaucratic conflicts? The next examples will very briefly illustrate the effect of Congress polarisation on bureaucratic conflicts.

During NAFTA, heated discussions surrounding the side agreements, which included labour and environmental matters, dragged the Congress into a clash between Democrats and Republicans. The Democrats, led by Richard Gephardt (D-MO) and in alignment with the demands of trade unions such as the AFL-CIO, believed that the side agreements should address the need to create commissions with enforcement powers in order to punish the members of NAFTA that disrespected the labour and environmental clauses of the side agreements. The Republicans, in turn, considered that such clauses should be left aside (Inside US Trade 1993b). The division was followed by bureaucratic conflicts, as expressed above. In spite of the fact that the NAFTA subject was gaining salience each day and that the Congress was becoming increasingly polarised, the year of 1993 was still the first year of the Clinton administration. The president, a new Democrat willing to satisfy both parties, had political power to overcome the growing polarisation surrounding NAFTA in order to get the agreement approved (Mayer 1998). As such, in spite of the constant attention of the bureaucrats towards the Congress, polarisation of the Congress was not the main explanation for bureaucratic conflicts.

The same applies to the USA's China and Japan policy during Clinton's early years as president. The majority of the Congress believed that there was the need for a more assertive approach primarily in order to 1) revert the growing US trade deficits and 2) to demonstrate US dissatisfaction with China's human right records. In these cases, as pointed out by the argument above, there was a considerable measure of bureaucratic conflict in the formulation stages. However, the division between Congress parties did not seem to have made these conflicts reach an unmanageable level.

The 1997 attempt to renew the fast-track offers a different perspective. During the process of formulating the fast-track proposal in 1997, there was a very high degree of polarisation in Congress. Bill Clinton had just been re-elected, which made Republicans furious and willing to embarrass Clinton by imposing Legislative losses on the Democrat party. This, in turn, considered that Clinton's trade policy during his first mandate had been too much aligned to the trade preferences of the Republican party. This polarisation had feedback on the position of the bureaucracy (Argument 3) by making an agreement more difficult to be attained. Considering that bureaucrats tried to anticipate the possibilities of a proposal being approved by the Congress, there was a very pronounced division within the administration.

On the one hand, the USTR was not that interested in the amount of time it would be necessary to invest to come up with a proposal, as long as it was considered the best possible agreement. On that note, Charlene Barshefsky affirmed that 'we do not have a schedule because it depends on our appreciation of the possibility of reaching a consensus' (Inside 
US Trade 1997b). On the other hand, other supporters, such as Kolbe (R-AZ) considered that there was a very short window of opportunity regarding the formulation of fast-track, and that the approval should come before the NAFTA follow-up report, to be launched by the administration in July 1997 (Inside US Trade 1997a; Devereaux et al 2006). This division resulted in the fast-track voting date being successively postponed, giving the chance for opponents to gather lobbying power and constraining potential supporters to launch an all-out campaign to get fast-track approved. In other words, political polarisation increased the bureaucratic divisions and resulted in a badly coordinated and late proposal.

Based on these examples it is likely that:

Argument 5: The more polarised the Congress, the higher the possibility of bureaucratic conflicts during the formulation stage.

The arguments of this subsection show that 1) the stage of the proposal (formulation or voting) matters as does 2) the presence of actors outside the foreign trade bureaucracy, such as the Congress and the President. These arguments put into perspective the criticism that, in view of the participation of the Congress and other relevant actors, such as the president, bureaucratic politics do not matter, and show, instead, when these conflicts actually matter. In spite of this initial effort, given the importance of outsiders in the interaction with the United States trade bureaucracy, future works should call more attention to the relation between bureaucrats and groups outside Executive.

\section{Conclusion}

This article is based on the evidence that recent trade policy works do not give due attention to bureaucratic conflicts, in spite of the existence of some resilient 'hall of fame' works. This is in part the result of the departure of the recent trade policy research from the foreign policy tradition to the more parsimonious tradition of political economy, which generally takes the Executive as a unitary actor. By using evidence from the US trade policy during the Clinton administration (1993-2001), I expected, in this article, to (1) illustrate that bureaucratic divisions matter in the study of trade policy in spite of the fact that the recent trade policy scholarship has paid little attention to bureaucratic conflicts, and to (2) present some elements to make the analysis of bureaucratic conflicts more palpable for means of studying the US trade policy by showing some examples of how and when they matter.

The examples I used evidenced that bureaucratic politics do matter in US trade policy, although these divisions will not always point to opposite world-views. Moreover, I showed through examples that the BPM resultant hypothesis is flawed, arguing that not always will bureaucracies reach a common ground in terms of trade policy. I argued, instead, that divisions are more likely to result in deadlocks, delays, and political 'zig-zagging. I also presented some arguments to show when and how 'outsiders' such as the president and the Congress are likely to influence bureaucratic conflicts and when bureaucratic conflicts are more relevant in the policymaking process.

The arguments put into perspective the critiques of the BPM model, illustrating, at least for the purposes of foreign trade policy research, that they do not overshadow the 
importance of bureaucratic conflicts. The relation between the section that presented the main elements of BPM along with its criticisms and the section that presented examplebased arguments is illustrative for that matter. The arguments presented are relevant for trade policy research in a context in which the mainstream IPE is being criticised for its growing focus on more and more disaggregated variables and even reductionism (Cohen 2008). By questioning the assumption of the Executive as a unitary actor, the paper draws attention to the complex nature of the trade policymaking process and highlights the need to expand the theoretical possibilities surrounding the study of US trade policy.

I conclude that, while the intrinsic flaws of the BPM are partially responsible for its diminished use as a model, bureaucratic conflicts are very relevant for the study of trade policy and should not be discarded. An agenda for future research in trade policy should, then, take into consideration the need to give flexibility to the assumption of the Executive as unitary actor. In addition, there are bright possibilities surrounding the study of the interaction between interest groups and the trade policy bureaucracy, on average more open to outsiders than the foreign and security policy bureaucracy. Also, the prospect of bureaucrats leaving office to take high-level positions within the industry that are part of the constituency of an agency, and vice-versa, can also lead to relevant trade policy studies, and are hardly available nowadays.

\section{Notes}

1 USTR's responsibilities include: 1) bilateral, regional and multilateral trade and investment issues; 2) expansion of market access for American goods and services; 3) international commodity agreements; 4) negotiations affecting US import policies; 5) oversight of the Generalised System of Preferences (GSP) and Section 301 complaints against foreign unfair trade practices, as well as Section 1377, Section 337, and import relief cases under Section 201;6) trade, commodity, and direct investment matters managed by international institutions such as the Organization for Economic Cooperation and Development (OECD) and the United Nations Conference on Trade and Development (UNCTAD); 7) trade-related intellectual property protection issues; 8)World Trade Organization (WTO) issues (Cohen, Blecker and Paul 2003).

2 The fast-track authority is an instrument delegated by the Congress to the Executive that allows a trade agreement to be negotiated without the possibility of amendments during the voting phase. It confers credibility to the US trade negotiating position, as it guarantees agility of the voting stage in the US Congress and is considered one of the main instruments of trade liberalisation at hand for the United States (Destler 2005; Cohen, Paul and Blecker 2003).

3 For the United States to be able to engage in free trade with a foreign nation, the status of most-favourednation (MFN) has to be granted. Usually it is granted automatically, but until 1999, China required an annual waiver according to the Jackson-Vanik amendment. Thus, the permanent MFN or permanent normal trade relations (PNTR) required the US to vote to change the Jackson-Vanik amendment in order to abolish the need for an annual waiver for China.

\section{References}

Allison, Graham and Morton Halperin. 1972. 'Bureaucratic Politics: A Paradigm and Some Policy Implications'. World Politics (24): 40-79.

Allison, Graham and Philip Zelikow. 1971. The Essence of Decision: Explaining the Cuban Missile Crisis. New York: Pearson. 
Alt, James and Michael Gilligan. 2000. 'The political economy of trading states: factor specificity, collective action problems, and domestic political institution'. In Jeffrey Frieden and David Lake (eds), International Political Economy: perspectives on global power and wealth. London: Routledge. pp. 327-42.

Art, Robert. 1973. 'Bureaucratic Politics and American Foreign Policy: A Critique’. Policy Sciences (4): 467-90.

Babington, Charles and Matthew Vita. 2000. 'President Begins Trade Push', Washington Post. 9 March. Bendor, Jonathan and Terry Moe. 1985. 'An adaptative model of bureaucratic politics' American Political Science Review 79 (3): 755-74.

Bentor, Jonathan and Thomas Hammond. 1992. 'Rethinking Allison's Models' American Political Science Review 86 (02): 301-22.

Bradsher, Keith. 1995. 'U.S. not embracing call for a shift on Japan'. New York Times, 2 August.

By, Keith. 1993. 'Labor secretary, despite opposition of unions, backs Mexico trade pact'. Wall Street Journal. 30 April.

Chorev, Nitsan. 2010. 'Fixing Globalization Institutionally: US Domestic Politics of International Trade'. International Sociology 25 (1): 54-74.

Clinton, Bill. 2004. My Life. New York: Alfred A. Knopf.

Cohen, Benjamin. 2008. International Political Economy: An Intellectual History. Princeton: Princeton University Press.

Cohen, Stephen. 2000. The Making of United States International Economic Policy: Principles, Problems, and Proposals for Reform. $5^{\text {th }}$ ed. Westport, CT: Praeger.

Cohen, Stephen, Joel Paul and Robert Blecker. 2003. Fundamentals of US foreign trade policy. Boulder: Westview Press.

Destler, Ian. 1980. Making Foreign Economic Policy. Washington: Brookings Institution Press. 1996. The National Economic Council: a work in progress. Washington: Institute for International Economics. 2005. American Trade Politics. $4^{\text {th }}$ ed. Washington: Institute for International Economics. 2010. 'The Foreign Economic Bureaucracy' In Steven Hook and Christopher Jones (eds). Routledge Handbook of American Foreign Policy. New York: Routledge. pp. 217-30.

Devereaux, Charan, Robert Lawrence and Michael Watkins. 2006. Case Studies in US Trade Policy. Vol.1: Making the Rules. Washington: Institute for International Economics.

Dolan, Christopher. 2002. Striking a balance: presidential power and the National Economic Council in the post-Cold War. PhD Thesis, University of North Carolina, US.

Dryden, Stephen. 1995. The Trade Warriors: USTR and the American Crusade for Free Trade. New York: Oxford University Press.

Freedman, Lawrence. 1976. 'Logic, Politics and Foreign Policy Processes: A Critique of the Bureaucratic Politics Model'. International Affairs 52 (3): 434-49.

Frieden, Jeffrey. 2000. ‘The Method of Analysis: Modern Political Economy’. In Jeffrey Frieden, Michael Pastor Jr. and Michael Tomz (eds), Modern Political Economy and Latin America: Theory and Policy. Boulder: Westview Press. pp. 37-43. 
George, Alexander. 1972. 'The Case for Multiple Advocacy in Making Foreign Policy'. American Political Science Review 66 (1): 751-85.

Gibson, Martha. 2000. Conflict amid consensus in American trade policy. Washington, DC: Georgetown University Press.

Goldstein, Judith. 1986. 'The Political Economy of Trade: Institutions of Protection'. American Political Science Review 80 (1): 161-84.

Henisz, Witold and Edward Mansfield. 2004. 'Votes and Vetoes: The Political Determinants of Commercial Oppeness'. International Studies Quarterly 50 (1): 189-212.

Hermann, Margareth. 2001. 'How Decision Units Shape Foreign Policy: A Theoretical Framework', International Studies Review 3 (2): 47-81.

Inside US Trade. 1993a. 'Watanabe Proposes New Approach To US-Japan Trade, Economic Problems'. 19 February.

. 1993b. 'Major Business Groups Signal Opposition To Us Drafts On Nafta Side Pacts' 4 June. 1993c. ‘Cutter To Lead U.S. Delegation At Framework Talks With Japan Next Week. 4 June. . 1993d. 'Pelosi Says China MFN Policy Should Set Conditions That Can Be Met By PRC'.

19 March.

1994a. 'UAW President Says Unity With Carmakers Limited To Fighting Japanese Surplus. 22 January.

. 1994b. 'Administration Facing Congressional Heat On Auto Talks With Japan'. 17 June. . 1997a. 'Kolbe Warns Barshefsky Of “Narrow Window” For Fast Track Passage'. 21

March.

. 1997b. 'USTR Official Says Congress Members Urged Delay On Fast-track Bill'. 28

March.

Judis, John. 1995. 'Sleazy genius'. The New Republic. 15 May.

Juster, Kenneth and Simon Lazarus. 1997. Making Economic Policy: An Assessment of the National Economic Council. Washington: Brookings Institution.

Karol, David. 2000. 'Divided Government and U.S. Trade Policy: Much Ado about Nothing?' International Organization 54 (4): 825-44.

Kissinger, Henry. 1966. 'Domestic Structure and Foreign Policy'. Daedalus 95 (2): 503-29.

Krasner, Stephen. 1972. 'Are Bureaucracies Important? (Or Allison Wonderland)'. Foreign Policy 7 (1): 159-79.

Levy, Jack. 2008. 'Case Studies: Types, Designs, and Logics of Inference'. Conflict Management and Peace Science 25 (1): 1-18.

Lohmann, Susan and Sharon O'Halloran. 1994. 'Divided Government and U.S. Trade Policy: Theory and Evidence.' International Organization 48 (4): 595-632.

Mansfield, Edward, Helen Milner and Peter Rosendorff. 2002. 'Why Democracies Cooperates: Electoral Control and International Trade Agreements'. International Organization 56 (3): 477-513.

Mayer, Frederich. 1998. Interpreting NAFTA: The Science and Art of Political Analysis. New York: Columbia University Press.

McCubbins, Matthew and Thomas Schwartz. 1984. 'Congressional Oversight Overlooked: Police Patrols versus Fire Alarms'. American Journal of Political Science 28 (1): 165-79. 
Milner, Helen. 1997. 'Actors' interests, policy preferences, and the demand for international cooperation'. In Helen Milner (ed), Interests, Institutions and Informations: Domestic Politics and International Relations. Princeton: Princeton University Press. pp. 33-66.

Orszag, John, Peter Orszag and Laura Tyson. 2002. 'The Process of Economic Policy-Making During the Clinton Administration'. In John Frankel and Peter Orszag (eds), American Economic Policy in the 1990s. Cambridge: MIT Press. pp. 983-1027.

Pastor, Robert. 1982. Congress and the Politics of US Foreign Economic Policy, 1929-1976. Berkeley: University of California Press.

Reich, Robert. 1998. Locked in the Cabinet. New York: Vintage.

Rhodes, Edward. 1994. 'Do Bureaucratic Politics Matter?: Some Disconfirming Findings from the Case of the U. S. Navy'. World Politics 47 (1): 1-41

Rosati, Jerel. 1981. 'Developing a systemic decisionmaking framework: Bureaucratic politics in perspective. World Politics 33 (2): 234-52.

Rubin, Robert and James Weisberg. 2003. In An Uncertain World: Tough Choices From Wall Street To Washington. New York: Random House.

Sanger, David. 1999. 'Near Miss on Trade Agreements May Have Stemmed from Clinton's Distractions'. The New York Times. 10 April.

Scheve, Kenneth and Mattheu Slaughter. 2001. 'What Determines IndividualTrade-Policy Preferences?' Journal of International Economics 54 (1): 267-92.

Sciolino, Elaine. 1994. 'U.S. to try a conciliatory tack with China'. New York Times. 23 March.

Seawright, Jason and John Gerring. 2008. 'Case Selection Techniques in Case Study Research: A Menu of Qualitative and Quantitative Options'. Political Research Quarterly 61 (2): 294-308.

Welch, David. 1992. 'The Organizational Process and Bureaucratic Politics Paradigms: Retrospect and Prospect'. International Security 17 (2): 112-46.

\section{About the author}

Rodrigo Fagundes Cézar is a PhD candidate in International Relations/Political Science at the Graduate Institute of International and Development Studies (IHEID), Switzerland. He holds a Master's degree in International Relations from the Pontifical Catholic University of São Paulo ('San Tiago Dantas' Post-Graduate Program), Brazil. He has worked at UNDP Brazil, and held a research fellowship position at the International Policy Centre for Inclusive Growth (IPC-IG). His PhD research ('The making of the trade-labor linkage in the United States and European Union') approaches the domestic determinants of labour standards in preferential trade agreements from a comparative perspective. His research interests include: foreign policy analysis, trade policymaking in the United States and European Union, and policy networks.

Received on 26 February 2016, and approved for publication on 11 October 2016.

(cc) BY-NC https://creativecommons.org/licenses/by-nc/4.0/ 